\title{
Animasi 3D untuk Media Sosialisasi Kanker Serviks pada Kelurahan Pekojan
}

\author{
Nurul Safitri, Eriya \\ Program Studi Teknik Multimedia dan Jaringan \\ Jurusan Teknik Informatika dan Komputer \\ Politeknik Negeri Jakarta \\ nunulangitan@gmail.com, eriya@tik.pnj.ac.id
}

Diterima: 9 Maret 2016. Disetujui: 16 April 2016. Dipublikasikan: Mei 2016

\begin{abstract}
Cervical cancer currently ranks second list of cancer in women. This is attributable to the lack of public knowledge about cervical cancer. From the results of questionnaires distributed to the member of PKK Pekojan known that over 50\% of people do not understand about cervical cancer. To avoid the increasing number of people who contract cervical cancer it takes a socialization. The goal, to help provide information about cervical cancer to communities in Kelurahan Pekojan. There are many ways to create a media socialization, one of which is to create an animation. Animation created to act as the introductory material cervical cancer, which will be explained in the motion graphic. The animation was created consisting of animated characters and animation assets. Testing method used is the alpha and beta test. Alpha testing is done to test the level of similarity with the original character of the animated character. While in beta test and the quality test results to see the animation through questionnaires by respondents consisting of PKK members Pekojan village itself. From the second test showed that by adding an animated 3D video output socialization cervical cancer then presented becomes more attractive, because there is a storyline that can facilitate PKK Village Pekojan understand the information conveyed.
\end{abstract}

Keywords: 3D animation, cervical cancer

\section{PENDAHULUAN}

Kanker merupakan penyakit yang disebabkan oleh ketidakteraturan perjalanan hormon yang mengakibatkan tumbuhnya daging pada jaringan tubuh yang normal atau bisa disebut juga tumor ganas. Kanker dapat menyerang berbagai jenis jaringan di dalam organ tubuh, salah satunya adalah alat reproduksi wanita. Menurut Pusat Data dan Informasi Kementerian Kesehatan RI (2013), penyakit kanker serviks saat ini menempati urutan kedua daftar kanker yang diderita kaum wanita, yang disebabkan oleh infeksi virus HPV (Human Papilloma Virus).

Kanker serviks biasanya dikenal dengan kanker leher rahim yang letaknya di antara rahim (uterus) dengan liang senggama wanita (vagina) [1]. Untuk menghindari semakin banyaknya masyarakat yang terjangkit kanker serviks maka dibutuhkan sebuah sosialisasi sehingga anggota masyarakat dapat belajar untuk mengenal dan menghayati kebudayaan dalam lingkungannya. Pada saat ini kegiatan sosialisasi masih dilakukan dengan penyuluhan-penyuluhan oleh dinas kesehatan ke berbagai daerah dan dengan menggunakan media cetak seperti brosur.

Dengan berkembangnya teknologi komputer terutama animasi, maka kegiatan sosialiasi dapat dilakukan dengan media animasi. Animasi adalah usaha untuk membuat presentasi statis menjadi hidup. Animasi merupakan perubahan visual sepanjang waktu yang memberi kekuatan besar pada proyek multimedia yang dibuat.

Computer Technology Research (CTR) menyatakan bahwa orang hanya mampu mengingat $20 \%$ dari yang dilihat dan $30 \%$ dari yang didengar. Tetapi orang dapat mengingat $50 \%$ dari yang dilihat dan didengar dan $80 \%$ dari yang dilihat, didengar dan dilakukan. Untuk itu, multimedia yang dalam konteks ini pembuatan animasi, menjadi salah satu media ampuh untuk pengajaran dan sosialisasi.

Berdasarkan hal tersebut, pada penelitian ini akan dibuat sebuah animasi 3D pada video sosialisasi kanker serviks untuk PKK (Pemberdayaan Kesejahteraan Keluarga) Kelurahan Pekojan, Tambora, Jakarta Barat, karena berdasarkan rekapitulasi kuesioner pre-test yang telah diberikan kepada 20 responden yang terdiri dari anggota PKK dan ibu rumah tangga di Kelurahan Pekojan menunjukkan bahwa lebih dari $50 \%$ responden belum memahami penyakit kanker serviks. Dengan dibuatnya animasi 3D pada sosialisasi kanker serviks ini diharapkan para wanita khususnya anggota PKK Kelurahan Pekojan dapat memahami bahaya dan melakukan pencegahan terhadap penyakit kanker serviks. 


\section{TINJAUAN PUSTAKA}

\section{A. Pengertian Animasi}

Animasi berasal dari kata "to animate" yang artinya membuat seolah-olah hidup dan bergerak [2]. Salah satu keunggulan animasi dibanding media lain seperti gambar statis atau teks adalah kemampuannya untuk menjelaskan perubahan keadaan tiap waktu [8]. Hal ini terutama sangat membantu dalam menjelaskan prosedur dan urutan kejadian.

\section{B. Jenis-jenis Animasi}

Animasi yang dulunya mempunyai prinsip sederhana, saat ini telah berkembang menjadi beberapa jenis, yaitu:

1) Animasi 2D (2 dimensi)

Animasi dua dimensi adalah teknik pembuatan animasi dengan menggunakan gambar bersumbu (axis) dua yaitu X dan Y [2]. Animasi ini lebih dikenal dengan animasi manual yang progresnya dimulai dengan menggambar di atas selembar kertas, kemudian di-scan dan baru dipindahkan ke dalam komputer untuk diubah menjadi file digital.

2) Animasi 3D (3 dimensi)

Animasi 3D adalah teknik pembuatan animasi pada sebuah bidang yang menggunakan tiga sumbu, yaitu $\mathrm{X}$, Y, dan Z sebagai sumbu kedalaman [2]. Objek yang dihasilkan bisa diputar berdasarkan ketiga sumbunya. Sumber yang sama (Gunawan, 2013) menambahkan, umumnya animasi 3D dikerjakan menggunakan komputer, yakni sudah berupa file digital walaupun untuk membuat modeling nya masih diperlukan gambar sketsa manual sebagai acuan.

3) Animasi Clay

Animasi clay merupakan animasi yang menggunakan plasticin, yaitu tanah liat berbahan lentur seperti permen karet, yang ditemukan pada tahun 1897 (Syahfitri, 2011). Tokoh pada animasi clay dibuat dengan menggunakan rangka khusus untuk kerangka tubuhnya.

\section{Prinsip Dasar Animasi}

Tujuan dari animasi adalah menyajikan cerita untuk menangkap gambar hidup dalam proses komunikasi [4]. Animator Walt Disney Studio, Frank Thomas dan Ollie Johnston membangun sebuah pedoman yang menjadi standar bagi industri animasi untuk membuat penonton merespon karakter dan cerita yang disampaikan oleh animasi yang dibuat. Prinsip ini mencakup tiga hal utama yang harus dilakukan untuk menjaga ketertarikan penonton. Animasi yang dibuat harus jelas dan dapat dipercaya. Pedoman tersebut dimuat pada tahun 1981 dalam buku yang berjudul "The Illusion of Life: Disney Animation”. Berikut adalah 12 prinsip dasar animasi tersebut:

\section{a) Squash and Stretch}

Contoh yang paling sederhana dari Squash and Stretch adalah bouncing ball. Ketika mengenai permukaan, ia akan pipih, dan ketika memantul ke atas ia akan meregang.

b) Anticipation

Anticipation membantu penonton memprediksi apa yang akan terjadi selanjutnya.

c) Staging

Staging adalah cara penempatan karakter di hadapan kamera. Dengan menempatkan kamera/karakter secara tepat, konsep yang diinginkan dapat terbaca dengan mudah oleh penonton.

d) Straight-Ahead Action and Pose to Pose Straight-Ahead Action adalah metode dengan menggambar secara berurutan, dari gambar pertama, kedua, ketiga, dan seterusnya. Sedangkan Pose to Pose segala pergerakan sudah direncanakan terlebih dahulu.

e) Follow Through and Overlapping Action

Prinsip animasi ini berdasarkan hukum kelembaman Newton. Misalnya, saat seseorang berlari, kemudian berhenti. Badan akan sedikit terlempar ke depan sebelum akhirnya kembali ke titik seimbang. Akan ditemukan "gerakan berlebih" pada setiap akhir gerakan yang dilakukan atau yang disebut follow through.

f) Tidak semua gerakan terjadi atau berhenti pada saat bersamaan. Selalu ada selang waktu antara gerakan utama dengan gerakan sekunder. Seringkali gerakan tersebut bertindihan (overlapping action).

\section{g) Slow In and Slow Out}

Dari suatu pose yang diam ke sebuah gerakan akan terjadi percepatan dan dari gerakan sebuah pose akan terjadi perlambatan.

h) Arcs

Arcs akan membuat gerakan animasi menjadi lebih alami, khususnya untuk gerakan manusia dan hewan. Pada saat menggelengkan kepala, gerakan yang dihasilkan adalah gerakan yang membentuk lingkaran (gerakan melengkung /arcs).

i) Secondary Action

Secondary Action adalah prinsip di mana ada gerakan sekunder yang terjadi akibat adanya gerakan utama. Gerakan sekunder ini tidak boleh melebihi gerakan utama.

j) Timing

Timing menentukan berapa gambar yang harus dibuat di antara dua pose atau yang biasa disebut inbetween.

\section{k) Exaggeration}

Pada intinya, prinsip exaggeration ini adalah untuk melebih-lebihkan aksi, ekspresi, atau apapun dalam animasi agar terlihat lebih menarik dan menampilkan kesan kartun.

1) Solid Drawing

Solid Drawing adalah kemampuan untuk menggambar karakter dalam berbagai angle 
sehingga karakter tersebut telihat 3D dan konsisten dalam setiap frame animasi.

m) Appeal

Appeal adalah bagaimana membuat karakter menjadi menarik, tidak selalu harus lucu seperti gambaran yang ada pada banyak kartun.

\section{Kanker Serviks}

Kanker leher rahim atau cervical cancer adalah jenis kanker yang paling banyak ditemukan pada wanita di Indonesia [5]. Kanker ini banyak menyebabkan kematian karena biasanya terlambat ditemukan atau diobati. Kanker serviks ini adalah tumor ganas yang tumbuh di dalam leher rahim, yaitu bagian terendah dari rahim yang menempel pada puncak vagina. Biasanya, kanker serviks menyerang wanita yang berusia 35-55 tahun. Hampir $90 \%$ dari kanker serviks berasal dari skuamosa yang melapisi serviks. Sedangkan $10 \%$ sisanya berasal dari sel kelenjar penghasil lendir pada saluran servikal yang menuju rahim.

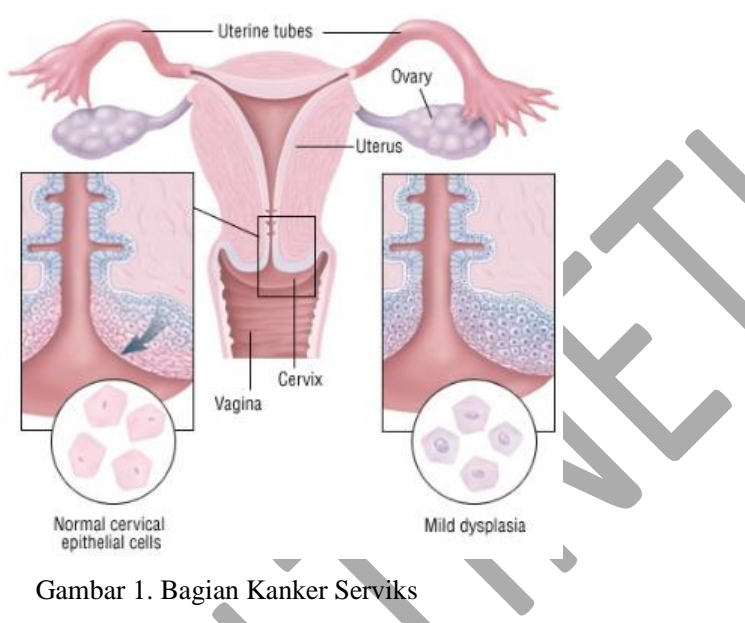

Beberapa faktor risiko yang berpengaruh terhadap terjadinya kanker serviks, yaitu:

a) Melakukan hubungan seksual pada usia dini.

b) Berganti-ganti pasangan seksual tanpa menggunakan kondom.

c) Pemakaian DES (dietilstilbestrol) pada wanita hamil.

d) Ganguan sistem kekebalan

e) Merokok

f) Pemakaian pil KB

g) Infeksi herpes genetalis atau infeksi klamidia menahun.

h) Defisien vitamin A, C, dan E.

i) Golongan ekonomi lemah karena tidak mampu melakukan Pap Smear secara rutin.

\section{METODE PENGEMBANGAN MULTIMEDIA}

Metode ini dilakukan dengan menerapkan metode Luther sebagai berikut:

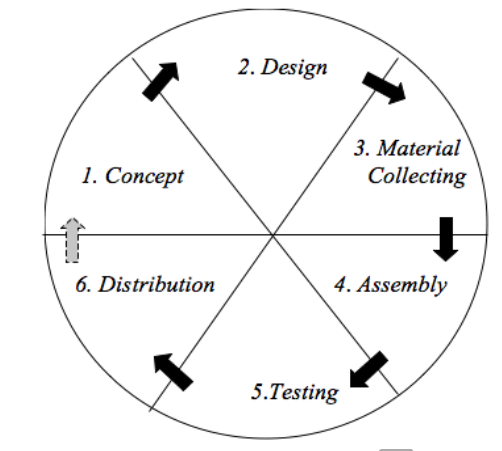

Gambar 2. Tahap Pengembangan Multimedia [6]

\section{a) Concept}

Tahap concept yaitu menentukan tujuan, termasuk identifikasi audiensi, macam aplikasi (animasi), dan tujuan aplikasi (media informasi) seperti Tabel 1.

\begin{tabular}{|l|l|}
\multicolumn{2}{|c|}{ TABEL 1. KONSEP PEMBUATAN ANIMASI 3D } \\
\hline Judul & $\begin{array}{l}\text { Pembuatan Animasi 3D pada Sosialiasi } \\
\text { Kanker Serviks untuk PKK Kelurahan } \\
\text { Pekojan }\end{array}$ \\
\hline Audiensi & Anggota PKK Kelurahan Pekojan \\
\hline $\begin{array}{l}\text { Jenis } \\
\text { Aplikasi }\end{array}$ & Animasi 3D \\
\hline Durasi & 00:00:55 \\
\hline Karakter & Narasumber, Penanya 1, dan Penanya 2 \\
\hline Asset & $\begin{array}{l}\text { Latar Karakter 2D, bagian serviks, virus } \\
\text { HPV, pap smear, bagian serviks, kursi, layar } \\
\text { proyektor, dan microphone }\end{array}$ \\
\hline Animasi & $\begin{array}{l}\text { Karakter Narasumber, Karakter Penanya 1, } \\
\text { Karakter Penanya 2, bagian serviks yang } \\
\text { terjangkit virus HPV, dan pap smear }\end{array}$ \\
\hline $\begin{array}{l}\text { Audio } \\
\text { Dubbing }\end{array}$ & .wav \\
\hline Output & .png; .mp4 \\
\hline
\end{tabular}

Berdasarkan tabel 1 dapat dijelaskan animasi 3D dibuat untuk memodelkan karakter dan aset yang ada pada cerita animasi yang akan dibuat. Setiap karakter dan aset dibuat dalam bentuk 3D yang akan digunakan sebagai media sosialisasi kanker serviks kepada masyarakat.

\section{b) Design}

Design (perancangan) adalah tahap pembuatan spesifikasi mengenai arsitektur produk, gaya, tampilan, dan kebutuhan material atau bahan untuk mendapatkan gambaran dan pemahaman mengenai produk multimedia yang akan dibuat. Gambar 3 adalah desain storyboard yang dibuat.

c) Material Collecting

Animasi 3D pada Video Sosialisasi Kanker Serviks untuk PKK Kelurahan Pekojan dibuat dengan mengumpulkan bahan menggunakan perangkat lunak Blender 2.76b untuk karakter dan aset 3D, Adobe Illustrator CS6 untuk membuat gambar 2D latar belakang karakter dan blueprint karakter, serta Adobe Audition CS6 untuk mengedit audio dubbing karakter 3D. Tabel 2 berisi materi yang digunakan dalam animasi 3D ini. 


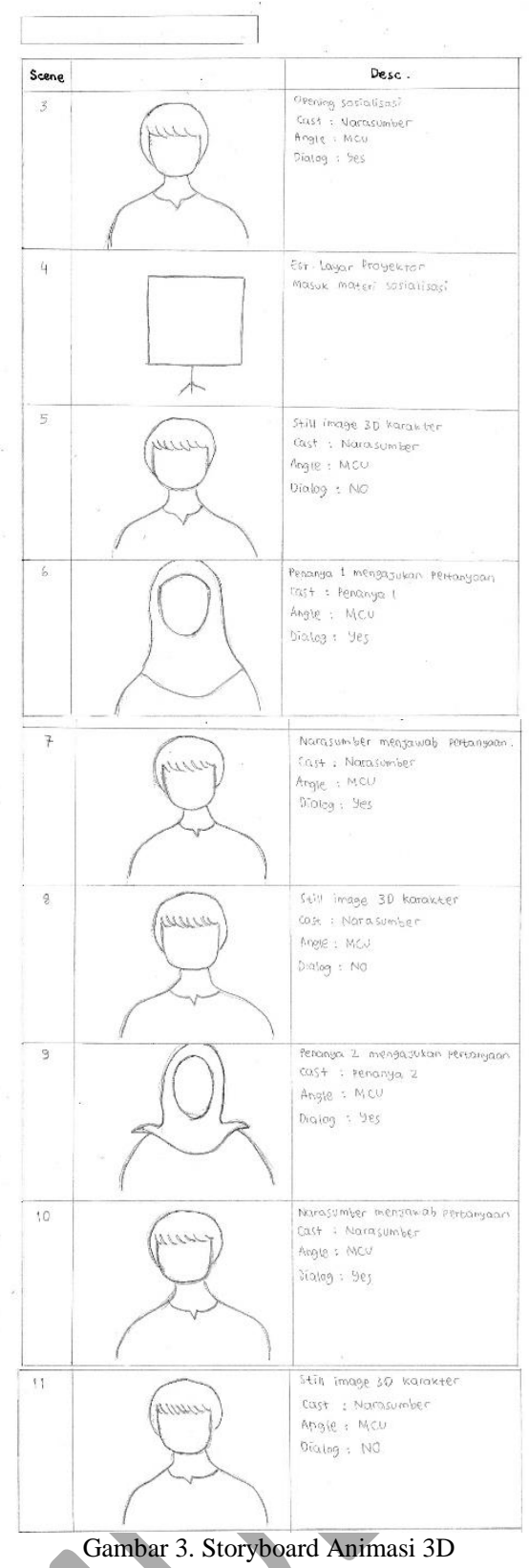

TABEL 2. MATERIAL COLLECTING

\begin{tabular}{|c|l|c|c|}
\hline No & Nama File & $\begin{array}{c}\text { Format } \\
\text { File }\end{array}$ & Gambar \\
\hline 1 & Background & .ai & \\
\hline 2 & Virus HPV & .png & \\
\hline 3 & Serviks & .png & \\
\hline
\end{tabular}

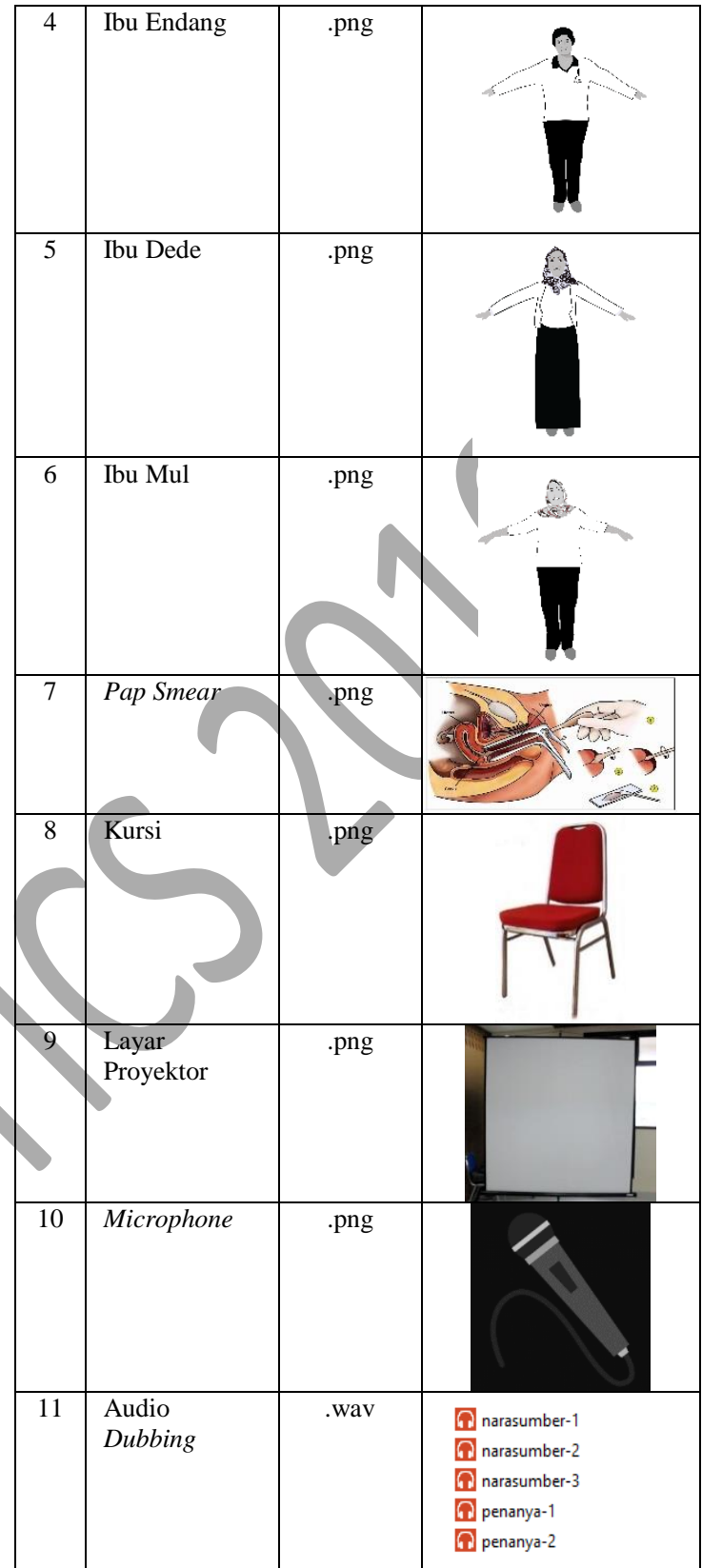

d) Assembly

Teknik pembuatan animasi 3D yang dilakukan terdapat di Gambar 4.

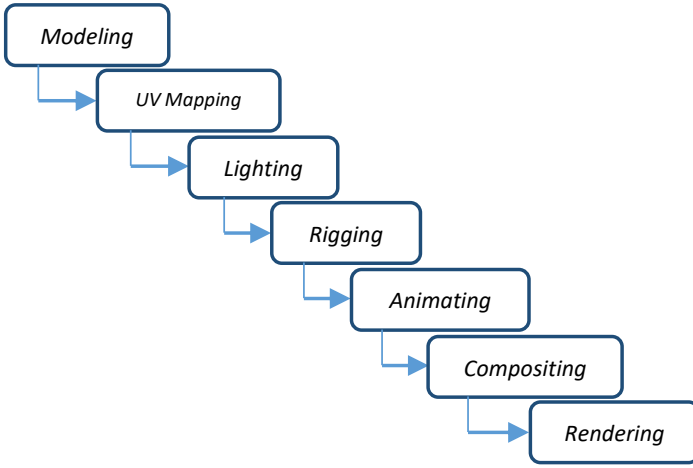

GAMBAR 4. ALUR PEMBUATAN ANIMASI 
1) Modelling adalah proses pembuatan sebuah model dalam bentuk visual 3D di komputer [4]. Proses pembentukan visual 3D pada Gambar 5 bisa terjadi karena memiliki tiga sumbu, yaitu $\mathrm{x}, \mathrm{y}$, dan $\mathrm{z}$. Dalam modeling, diterapkan teknik sebagai berikut: Mesh editing, subdividing, dan sculpting.

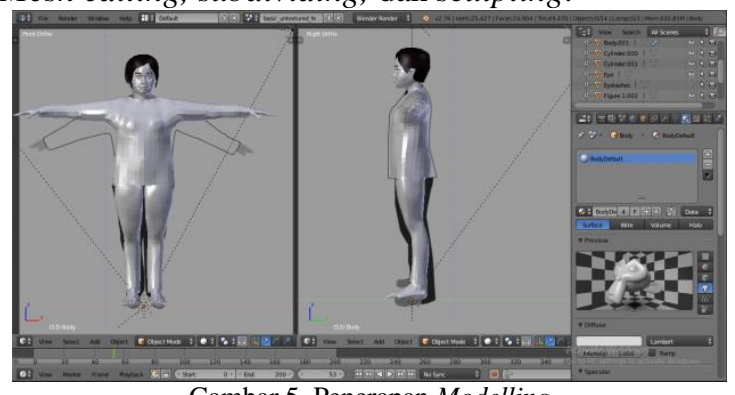

Gambar 5. Penerapan Modelling

2) $\boldsymbol{U} \boldsymbol{V}$ Mapping adalah langkah untuk memetakan model detail dengan menggunakan sistem koordinat [4]. Penerapan UV mapping terdapat di Gambar 6.

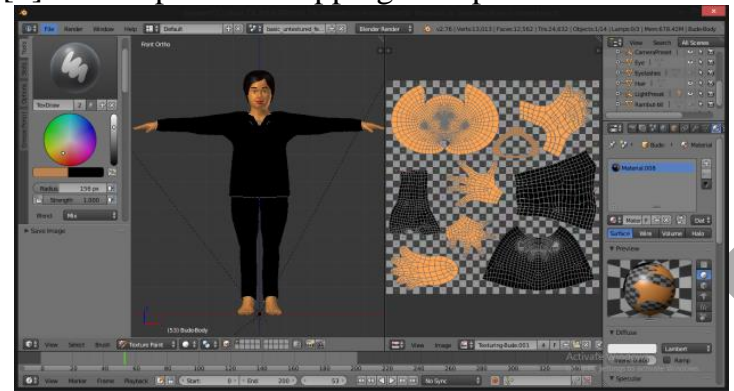

Gambar 6. Penerapan UV Mapping

3) Lighting adalah proses pembuatan dan pemberian cahaya pada model seperti pada Gambar 7 sehingga diperoleh kesan yisual yang realistis karena terdapat kesan kedalaman ruang dan pembayangan objek [4]

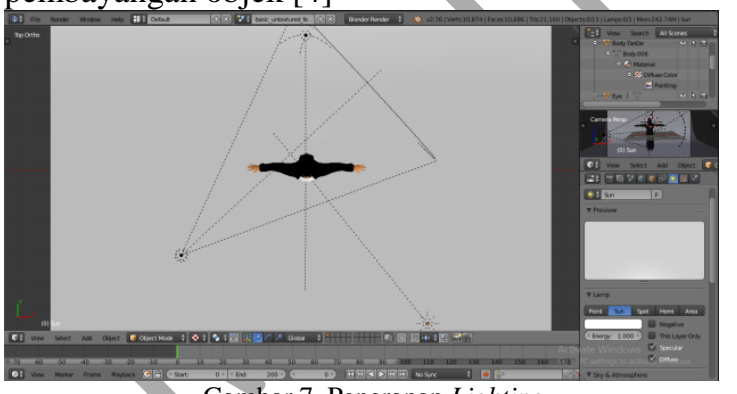

Gambar 7. Penerapan Lighting

4) Rigging merupakan fase pemberian tulang untuk mengontrol masing-masing objek yang akan digerakkan dalam proses animating [7]. Penerapan rigging terdapat di Gambar 8 .

5) Animating pada Gambar 8 adalah langkah untuk memberikan keyframe pada empat kegiatan, yaitu memberikan pose pada karakter, penyesuaian gerak mulut dengan audio dubbing, memberikan gerakan pada mata, dan penempatan angle kamera [7].

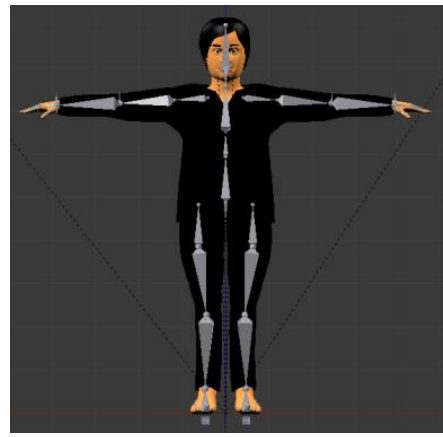

Gambar 8. Penerapan Ridging

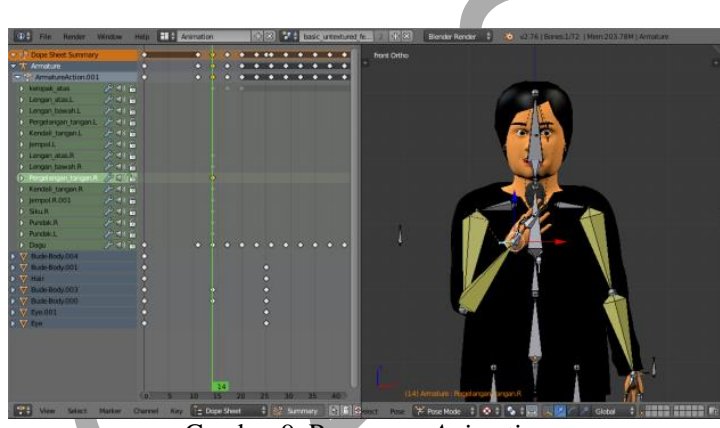

Gambar 9. Penerapan Animating

6) Compositing adalah proses secara digital menyusun gambar atau gambar sekuen secara tumpang tindih ke dalam suatu potongan gambar bergerak (motion picture) atau video digital [6]. Penerapan compositing terdapat pada Gambar 10.

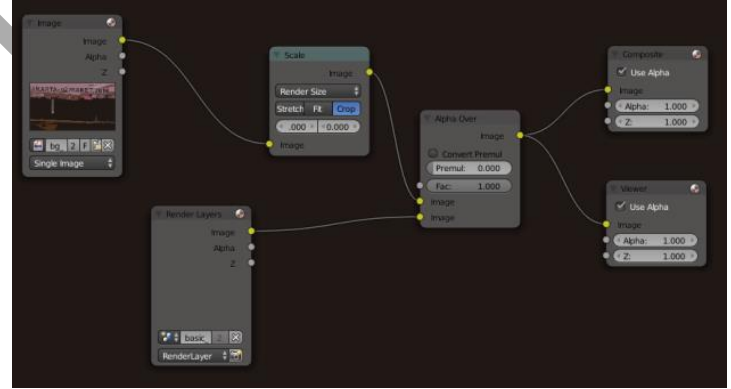

Gambar 10. Penerapan Compositing

7) Rendering pada Gambar 11 adalah proses pengkalkulasian akhir dari keseluruhan proses dalam pembuatan gambar ataupun animasi 3D.

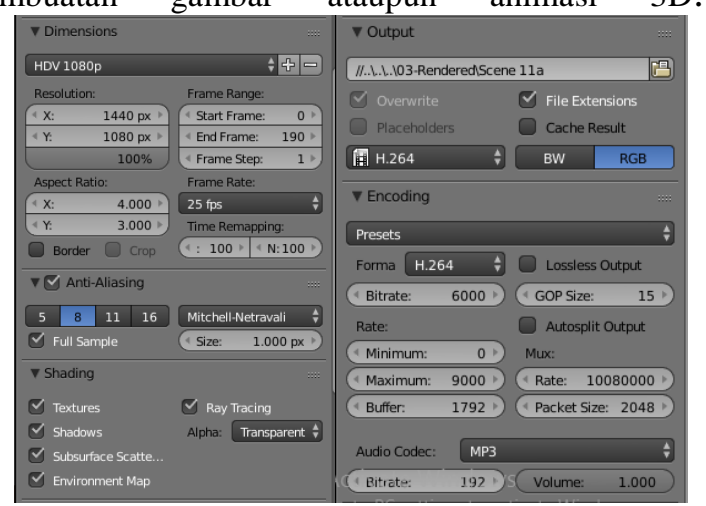

Gambar 11. Penerapan Rendering 


\section{METODE PENGUJIAN}

Pada metode ini dilaksanakan dua jenis pengujian, yaitu alpha dan beta. Pengujian alpha dilakukan oleh user pada lingkungan pengembang untuk mengendalikan error system agar segera dilakukan perbaikan. Sedangkan untuk pengujian beta dilakukan oleh beta tester yang terdiri dari 20 responden anggota PKK Kelurahan Pekojan. Tujuan pengujian ini adalah untuk menguji kualitas animasi 3D dan mengukur pemahaman responden.

\section{A. Pengujian Alpha}

Pengujian ini dilakukan dengan melihat kembali hasil video yang telah dirender, dan memastikan bahwa animasi yang berjalan sesuai dengan storyboard dan prinsip perancangan animasi.

1) Pengujian berdasarkan storyboard

Pengujian ini dilakukan untuk mengecek animasi yang telah dibuat apakah sesuai dengan storyboard atau tidak. Dari pengujian yang dilakukan didapatkan kesimpulan bahwa animasi yang dibuat telah sesuai dengan storyboard.

2) Pengujian berdasarkan 12 prinsip animasi

Pengujian ini dilakukan untuk menguji animasi yang dibuat berdasarkan 12 prinsip perancangan animasi.

\section{B. Pengujian Beta}

Pengujian beta pada animasi 3D Video Sosialisasi ini dilakukan dengan menyebarkan kuesioner dengan teknik random berstrata atau Stratified Random Sampling [8]. Kuesioner yang dibuat disebarkan kepada 20 dari 80 responden yang terdiri dari anggota PKK Kelurahan Pekojan, di mana menurut Nasution (2003) jumlah sampel diambil 25\% dari populasi responden [5]. Pengujian ini dilakukan secara door to door ke rumah anggota PKK Kelurahan Pekojan, karena saat bulan Ramadhan tidak ada kegiatan bertujuan untuk mengetahui feedback dari responden, sehingga feedback tersebut dapat memberi kesimpulan bahwa animasi 3D pada sosialisasi kanker serviks ini layak menjadi media sosialisasi di Kelurahan Pekojan.

\section{Hasil dan Pembahasan}

1) Hasil Pengujian Alpha berdasarkan storyboard terdapat di Tabel 3. Sedangkan Tabel 4 berisi pengujian berdasarkan 12 prinsip animasi.

TABEL 3. HASIL PENGUJIAN ALPHA BERDASARKAN STORYBOARD

\begin{tabular}{|l|l|l|l|c|}
\hline No & $\begin{array}{c}\text { Aspe } \\
\mathbf{k} \\
\text { yang } \\
\text { diuji }\end{array}$ & $\begin{array}{c}\text { Hasil yang } \\
\text { Diharapkan }\end{array}$ & $\begin{array}{c}\text { Hasil yang } \\
\text { Didapat }\end{array}$ & $\begin{array}{c}\text { Hasil } \\
\text { Testing }\end{array}$ \\
\hline 1 & $\begin{array}{l}\text { Scene } \\
3\end{array}$ & $\begin{array}{l}\text { Animasi yang } \\
\text { dihasilkan } \\
\text { sesuai dengan } \\
\text { storyboard } \\
\text { scene 3 }\end{array}$ & $\begin{array}{l}\text { Animasi yang } \\
\text { dihasilkan } \\
\text { sesuai dengan } \\
\text { storyboard } \\
\text { scene 3 }\end{array}$ & Sesuai \\
\hline
\end{tabular}

\begin{tabular}{|c|c|c|c|c|}
\hline 2 & $\begin{array}{l}\text { Scene } \\
4\end{array}$ & $\begin{array}{l}\text { Animasi yang } \\
\text { dihasilkan } \\
\text { sesuai dengan } \\
\text { storyboard } \\
\text { scene } 4\end{array}$ & $\begin{array}{l}\text { Animasi yang } \\
\text { dihasilkan } \\
\text { sesuai dengan } \\
\text { storyboard } \\
\text { scene } 4\end{array}$ & Sesuai \\
\hline 3 & $\begin{array}{l}\text { Scene } \\
5\end{array}$ & $\begin{array}{l}\text { Animasi yang } \\
\text { dihasilkan } \\
\text { sesuai dengan } \\
\text { storyboard } \\
\text { scene } 5 \\
\end{array}$ & $\begin{array}{l}\text { Animasi yang } \\
\text { dihasilkan } \\
\text { sesuai dengan } \\
\text { storyboard } \\
\text { scene } 5\end{array}$ & Sesuai \\
\hline 4 & $\begin{array}{l}\text { Scene } \\
6\end{array}$ & $\begin{array}{l}\text { Animasi yang } \\
\text { dihasilkan } \\
\text { sesuai dengan } \\
\text { storyboard } \\
\text { scene } 6\end{array}$ & $\begin{array}{l}\text { Animasi yang } \\
\text { dihasilkan } \\
\text { sesuai dengan } \\
\text { storyboard } \\
\text { scene } 6\end{array}$ & Sesuai \\
\hline 5 & $\begin{array}{l}\text { Scene } \\
7\end{array}$ & $\begin{array}{l}\text { Animasi yang } \\
\text { dihasilkan } \\
\text { sesuai dengan } \\
\text { storyboard } \\
\text { scene } 7\end{array}$ & $\begin{array}{l}\text { Animasi yang } \\
\text { dihasilkan } \\
\text { sesuai dengan } \\
\text { storyboard } \\
\text { scene } 7\end{array}$ & Sesuai \\
\hline 6 & $\begin{array}{l}\text { Scene } \\
8\end{array}$ & $\begin{array}{l}\text { Animasi yang } \\
\text { dihasilkan } \\
\text { sesuai dengan } \\
\text { storyboard } \\
\text { scene } 8\end{array}$ & $\begin{array}{l}\text { Animasi yang } \\
\text { dihasilkan } \\
\text { sesuai dengan } \\
\text { storyboard } \\
\text { scene } 8\end{array}$ & Sesuai \\
\hline 7 & & $\begin{array}{l}\text { Animasi yang } \\
\text { dihasilkan } \\
\text { sesuai dengan } \\
\text { storyboard } \\
\text { scene } 9 \\
\end{array}$ & $\begin{array}{l}\text { Animasi yang } \\
\text { dihasilkan } \\
\text { sesuai dengan } \\
\text { storyboard } \\
\text { scene } 9 \\
\end{array}$ & Sesuai \\
\hline & $\begin{array}{l}\text { Scene } \\
10\end{array}$ & $\begin{array}{l}\text { Animasi yang } \\
\text { dihasilkan } \\
\text { sesuai dengan } \\
\text { storyboard } \\
\text { scene } 10\end{array}$ & $\begin{array}{l}\text { Animasi yang } \\
\text { dihasilkan } \\
\text { sesuai dengan } \\
\text { storyboard } \\
\text { scene } 10\end{array}$ & Sesuai \\
\hline 9 & $\begin{array}{l}\text { Scene } \\
11\end{array}$ & $\begin{array}{l}\text { Animasi yang } \\
\text { dihasilkan } \\
\text { sesuai dengan } \\
\text { storyboard } \\
\text { scene } 11 \\
\end{array}$ & $\begin{array}{l}\text { Animasi yang } \\
\text { dihasilkan } \\
\text { sesuai dengan } \\
\text { storyboard } \\
\text { scene } 11 \\
\end{array}$ & Sesuai \\
\hline
\end{tabular}

TABEL 4. HASIL PENGUJIAN ALPHA BERDASARKAN 12 PRINSIP ANIMASI

\begin{tabular}{|c|c|c|c|c|}
\hline No & $\begin{array}{l}\text { Aspek } \\
\text { yang } \\
\text { diuji }\end{array}$ & $\begin{array}{c}\text { Hasil yang } \\
\text { Diharapkan }\end{array}$ & $\begin{array}{c}\text { Hasil yang } \\
\text { Didapat }\end{array}$ & $\begin{array}{c}\text { Hasil } \\
\text { Testing }\end{array}$ \\
\hline 1 & $\begin{array}{l}\text { Squash } \\
\text { and } \\
\text { Stretch }\end{array}$ & $\begin{array}{l}\text { Tidak } \\
\text { diterapkan }\end{array}$ & $\begin{array}{l}\text { Tidak } \\
\text { diterapkan }\end{array}$ & Sesuai \\
\hline 2 & $\begin{array}{l}\text { Anticipati } \\
\text { on }\end{array}$ & $\begin{array}{l}\text { Memberikan } \\
\text { tanda pada } \\
\text { penonton } \\
\text { mengenai apa } \\
\text { yang akan } \\
\text { dilakukan } \\
\text { oleh karakter }\end{array}$ & $\begin{array}{l}\text { Gerakan } \\
\text { karakter } \\
\text { narasumber } \\
\text { ntuk } \\
\text { mengarahkan } \\
\text { peserta } \\
\text { sosialiasi } \\
\text { melihat ke } \\
\text { layar } \\
\text { proyektor }\end{array}$ & Sesuai \\
\hline 3 & Staging & $\begin{array}{l}\text { Penempatan } \\
\text { karakter di } \\
\text { hadapan } \\
\text { kamera untuk } \\
\text { menampilkan } \\
\text { karakter } \\
\text { dengan jelas }\end{array}$ & $\begin{array}{l}\text { Penempatan } \\
\text { karakter pada } \\
\text { angle medium } \\
\text { close up. }\end{array}$ & Sesuai \\
\hline 4 & $\begin{array}{l}\text { Straight- } \\
\text { Ahead } \\
\text { and Pose } \\
\text { to Pose }\end{array}$ & $\begin{array}{l}\text { Tidak } \\
\text { diterapkan }\end{array}$ & $\begin{array}{l}\text { Tidak } \\
\text { diterapkan }\end{array}$ & Sesuai \\
\hline
\end{tabular}




\begin{tabular}{|c|c|c|c|c|}
\hline 5 & $\begin{array}{l}\text { Follow } \\
\text { Through } \\
\text { and } \\
\text { Overlapp } \\
\text { ing } \\
\text { Action }\end{array}$ & $\begin{array}{l}\text { Tidak } \\
\text { diterapkan }\end{array}$ & $\begin{array}{l}\text { Tidak } \\
\text { diterapkan }\end{array}$ & Sesuai \\
\hline 6 & $\begin{array}{l}\text { Slow In } \\
\text { and Slow } \\
\text { Out }\end{array}$ & $\begin{array}{l}\text { Tidak } \\
\text { diterapkan }\end{array}$ & $\begin{array}{l}\text { Tidak } \\
\text { diterapkan }\end{array}$ & Sesuai \\
\hline 7 & Arcs & $\begin{array}{l}\text { Membuat } \\
\text { gerakan } \\
\text { animasi } \\
\text { menjadi lebih } \\
\text { alami }\end{array}$ & $\begin{array}{l}\text { Sistem } \\
\text { pergerakan } \\
\text { badan } \\
\text { karakter } \\
\text { mengikuti } \\
\text { pola }\end{array}$ & Sesuai \\
\hline 8 & $\begin{array}{l}\text { Secondar } \\
\text { y Action }\end{array}$ & $\begin{array}{l}\text { Tidak } \\
\text { diterapkan }\end{array}$ & $\begin{array}{l}\text { Tidak } \\
\text { diterapkan }\end{array}$ & Sesuai \\
\hline 9 & Timing & $\begin{array}{l}\text { Tidak } \\
\text { diterapkan }\end{array}$ & $\begin{array}{l}\text { Tidak } \\
\text { diterapkan }\end{array}$ & Sesuai \\
\hline 10 & $\begin{array}{l}\text { Exaggera } \\
\text { tion }\end{array}$ & $\begin{array}{c}\text { Tidak } \\
\text { diterapkan }\end{array}$ & $\begin{array}{c}\text { Tidak } \\
\text { diterapkan }\end{array}$ & Sesuai \\
\hline 11 & $\begin{array}{l}\text { Solid } \\
\text { Drawing }\end{array}$ & $\begin{array}{c}\text { Tidak } \\
\text { diterapkan }\end{array}$ & $\begin{array}{c}\text { Tidak } \\
\text { diterapkan }\end{array}$ & Sesuai \\
\hline 12 & Appeal & $\begin{array}{c}\text { Tidak } \\
\text { diterapkan }\end{array}$ & $\begin{array}{c}\text { Tidak } \\
\text { diterapkan }\end{array}$ & Sesuai \\
\hline
\end{tabular}

2) Hasil Pengujian Beta

Data disusun berdasarkan pertanyaan dengan penyajian berbentuk tabel. Lalu jumlah dari setiap jawaban dihitung persentasenya dengan perbandingan jumlah responden 20 orang seperti terdapat di Tabel 5. Hasil pengujian terdapat di Tabel 6, 7, 8, 9, 10, dan 11 .

TABEL 5. DISTRIBUSI RESPONDEN BERDASARKAN USIA

\begin{tabular}{cc}
\hline Usia & $\mathbf{N}$ \\
\hline $21-30$ & 2 \\
$31-40$ & 6 \\
$41-50$ & 12 \\
\hline Total & 20 \\
\hline
\end{tabular}

TABEL 6. HASIL PENGUJIAN BERDASARKAN PERNYATAAN "KUALITAS ANIMASI PADA VIDEO SOSIALISASI SUDAH BAIK"

\begin{tabular}{|c|c|c|}
\hline Jawaban & $\begin{array}{c}\text { Jumlah } \\
\text { Responden }\end{array}$ & Persentase \\
\hline Sangat Setuju & 3 & $15 \%$ \\
\hline Setuju & 17 & $85 \%$ \\
\hline Agak Setuju & 0 & $0 \%$ \\
\hline Tidak Setuju & 0 & $0 \%$ \\
\hline Sangat Tidak Setuju & 0 & $0 \%$ \\
\hline \multicolumn{2}{r}{ Total } & $\mathbf{1 0 0 \%}$ \\
\hline
\end{tabular}

TABEL 7. HASIL PENGUJIAN BERDASARKAN PERNYATAAN "TAMPILAN ANIMASI PADA VIDEO SOSIALISASI MENARIK"

\begin{tabular}{|c|c|c|}
\hline Jawaban & $\begin{array}{c}\text { Jumlah } \\
\text { Responden }\end{array}$ & Persentase \\
\hline Sangat Setuju & 1 & $5 \%$ \\
\hline Setuju & 19 & $95 \%$ \\
\hline Agak Setuju & 0 & $0 \%$ \\
\hline Tidak Setuju & 0 & $0 \%$ \\
\hline Sangat Tidak Setuju & 0 & $0 \%$ \\
\hline \multicolumn{2}{|r|}{ Total } & $\mathbf{1 0 0 \%}$ \\
\hline
\end{tabular}

TABEL 8. HASIL PENGUJIAN BERDASARKAN PERNYATAAN "INFORMASI PADA ANIMASI BAGIAN SERVIKS DAN PAP SMEAR SUDAH BAIK DAN JELAS"

\begin{tabular}{|c|c|c|}
\hline Jawaban & $\begin{array}{c}\text { Jumlah } \\
\text { Responden }\end{array}$ & Persentase \\
\hline Sangat Setuju & 11 & $55 \%$ \\
\hline Setuju & 8 & $40 \%$ \\
\hline Agak Setuju & 1 & $5 \%$ \\
\hline Tidak Setuju & 0 & $0 \%$ \\
\hline Sangat Tidak Setuju & 0 & $0 \%$ \\
\hline \multicolumn{2}{r|}{ Total } & $\mathbf{1 0 0 \%}$ \\
\hline
\end{tabular}

TABEL 9. HASIL PENGUJIAN BERDASARKAN "PENAMBAHAN ANIMASI PADA VIDEO SOSIALISASI MEMBUAT TAMPILAN LEBIH MENARIK"

\begin{tabular}{|c|c|c|}
\hline Jawaban & $\begin{array}{c}\text { Jumlah } \\
\text { Responden }\end{array}$ & Persentase \\
\hline Sangat Setuju & 4 & $20 \%$ \\
\hline Setuju & 16 & $80 \%$ \\
\hline Agak Setuju & 0 & $0 \%$ \\
\hline Tidak Setuju & 0 & $0 \%$ \\
\hline Sangat Tidak Setuju & 0 & $0 \%$ \\
\hline \multicolumn{2}{|r|}{ Total } & $\mathbf{1 0 0 \%}$ \\
\hline
\end{tabular}

TABEL 10. HASIL PENGUJIAN BERDASARKAN "KUALITAS PENGISIAN SUARA PADA ANIMASI BAIK"

\begin{tabular}{|c|c|c|}
\hline Jawaban & $\begin{array}{c}\text { Jumlah } \\
\text { Responden }\end{array}$ & Persentase \\
\hline Sangat Setuju & 2 & $10 \%$ \\
\hline Setuju & 17 & $85 \%$ \\
\hline Agak Setuju & 1 & $5 \%$ \\
\hline Tidak Setuju & 0 & $0 \%$ \\
\hline Sangat Tidak Setuju & 0 & $0 \%$ \\
\hline \multicolumn{2}{r}{ Total } & $\mathbf{1 0 0 \%}$ \\
\hline
\end{tabular}

TABEL 11. HASIL PENGUJIAN BERDASARKAN PERNYATAAN "INTONASI DAN PELAFALAN KALIMAT PENGISIAN SUARA SUDAH BAIK DAN JELAS"

\begin{tabular}{|c|c|c|}
\hline Jawaban & $\begin{array}{c}\text { Jumlah } \\
\text { Responden }\end{array}$ & Persentase \\
\hline Sangat Setuju & 1 & $5 \%$ \\
\hline Setuju & 15 & $75 \%$ \\
\hline Agak Setuju & 4 & $20 \%$ \\
\hline Tidak Setuju & 0 & $0 \%$ \\
\hline Sangat Tidak Setuju & 0 & $0 \%$ \\
\hline \multicolumn{2}{r|}{ Total } & $\mathbf{1 0 0 \%}$ \\
\hline
\end{tabular}

Dari hasil evaluasi diperoleh bahwa dengan menambahkan animasi 3D pada video sosialisasi kanker serviks dapat menampilkan output yang lebih menarik, karena terdapat alur cerita yang dapat memudahkan user memahami informasi yang disampaikan.

\section{Distribution}

Setelah melewati pengujian alpha dan beta, maka tahap selanjutnya adalah tahap pendistribusian produk. Pendistribusian produk dilakukan dengan menyusun hasil animasi 3D dengan real video dan motion graphic, kemudian hasil compositing video tersebut di-render menjadi file berekstensi .mp4 dan dikemas ke dalam bentuk DVD. 


\section{KESIMPULAN}

Berdasarkan hasil penelitian yang telah dikerjakan, dapat disimpulkan bahwa:

a) Penelitian ini telah berhasil membuat sebuah animasi 3D sebagai visualisasi karakter, aset bagian serviks dan pap smear pada Video Sosialisasi Kanker Serviks untuk PKK Kelurahan Pekojan.

b) Pembuatan animasi 3D pada video sosialisasi kanker serviks sudah sesuai dengan prinsip animasi anticipation, staging, dan arcs.

c) Animasi 3D pada sosialiasi kanker serviks mudah dipahami oleh PKK Kelurahan Pekojan.

Adapun saran yang diberikan adalah:

1) Pada saat texturing objek dengan UV Mapping, jika warna objek menjadi merah muda maka user disarankand untuk memperhatikan tab materials pada panel properties, kemudian hapus bagian tekstur yang tidak ingin digunakan.

2) Jika warna yang dihasilkan objek terlalu mengkilap, user disarankan untuk mengurangi nilai intensity pada opsi Specular pada tab materials untuk menghasilkan warna yang lebih natural.

3) Saat melakukan rigging, pastikan sumbu axis setiap bonesnya sama agar saat merotasi dapat menghasilkan gerakan yang seimbang.

4) Pastikan Alpha Mode yang dipilih adalah Transparent untuk membuat latar belakang karakter menjadi transparan.

5) Jika ada bagian tubuh karakter yang tidak dapat digerakkan walaupun sudah diparent, user disarankan untuk memeriksa pewarnaan pada Weight Paint Mode.
6) Untuk mengurangi kemungkinan kehilangan data pada Blender, dapat digunakan fungsi Autosave pada tab File yang terdapat di User Preferences.

7) Dalam membuat animasi 3D, diperlukan pemahaman mendalam mengenai workflow dan pemahaman terhadap target audiensinya, agar animasi yang dihasilkan dapat memenuhi user requirement.

\section{REFERENSI}

[1] Arisusilo, Cahyawati 2012, 'Kanker Leher Rahim (Cervical Cancer) sebagai Pembunuh Wanita Terbanyak di Negara Berkembang', Jurnal Saintis, vol.1, no.1. Dapat diakses dari $:<\underline{\text { http://ejournal.uin-malang.ac.id/index.php/saintis/article/ }}$ view/1862/pdf >. [26 Januari 2016].

[2] Gunawan, Bambi Bambang. 2013. Nganimasi Bersama Mas Be!. Jakarta: PT Elex Media Komputindo.

[3] Utami, Dina 2011. 'Animasi dalam Pembelajaran', Majalah Ilmiah Pembelajaran, vol.7, no.1, pp.44.

[4] Chopine, Ami. 2011. 3D Art Essentials The Fundamentals of 3D Modeling and Animation. Oxford, UK: Focal Press.

[5] Prayitno, Sunyoto 2014. Buku Lengkap Kesehatan Organ Reproduksi Wanita. Jakarta: Saufa.

[6] Rahmad, Cito Yasuki 2011. 'Digital Compositing dalam Film Animasi 3 Dimensi', CAPTURE Jurnal Seni Media Rekam, vol.3, no.1, pp.13-16.

[7] Kasih, Intan Fatihah 2015. Animating Karakter dan Authoring pada Pengembangan Video Multimedia Interaktif 3D Fabel Untuk Anak TK, Skripsi D4, Politeknik Negeri Jakarta.

[8] Nasution, Rozaini 2003. 'Teknik Sampling', USU Digital Library. Dapat diakses dari: <http://library.usu.ac.id/ download/fkm/fkm-rozaini.pdf\&ved=0ahUKEwiGvsayhM PNAhUMo48KHSm2C8wQFggjMAM\&usg=AFQjCNHsCI QNOGbS2i8i7U_Izg1s9ZgU_w\&sig2=XL6AVjv9qRPdrfad 5LcKIQ>. [14 Juni 2016]. 